\title{
AZ EISZ HATÁRON TÚLI MAGYAR INTÉZMÉNYEKET SEGÍTŐ PROJEKTJE
}

Dr. Lencsés Ákos

\section{BEVEZETÉS}

Az Elektronikus Információszolgáltatás Nemzeti Program feladata a kutatási és közművelődési feladatok támogatása a magyar intézményi hálózat számára. A közel két évtizede múködő nemzeti program a feladatait szakirodalmi adatbázisok konzorciumi szintű beszerzésén keresztül végzi. A konzorciumi együttműködés jelentősen támogatja a gyarapítási folyamatokat az intézmények számára, aminek részeként a kiadói tárgyalások lefolytatásával, a közbeszerzési eljárások lebonyolításával, illetve az egyes adatbázisok előfizetési díjára biztosított központi támogatással segíti a tagintézményeket. A konzorciumi képviselet lehetőséget ad a szolgáltatók felé a teljes intézményi kör igényeinek egységes és következetes kommunikációjára, a magyar kutatói közösség érdekeinek érvényesítésére.

Ilyen intézményi érdek természetesen, hogy a konzorciumi szerződésben biztosított előfizetési díj kedvezőbb legyen az egyéni előfizetési díjnál. De emellett számtalan olyan szempont is felmerül, amelyet könnyebben lehet konzorciumi keretek között érvényesíteni (címlisták biztosítása, átlátható felhasználási feltételek, kutatásmódszertani képzések szervezése stb.). ${ }^{1}$ Az elmúlt években az egyik legfontosabb előrelépést jelentette az open access publikálás lehetőségének biztosítása a magyar kutatók számára. Az első open access szerződést 2018-ban kötötte az EISZ. Ennek köszönhetően az adott kiadói adatbázisra alakuló konzorcium tagintézményei a kutatóik számára további költségek nélkül biztosíthatták elfogadott tanulmányaik open access megjelenését. 2019-ben már nyolc kiadói open access szerződést kötött az EISZ, aminek eredményeként közel 4 millió euró megtakarítást ért el országos szinten. 2020-ban már 11 kiadói szerződés segíti a magyar kutatók számára az open access publikálás lehetőségét. ${ }^{2}$

\section{HATÁRON TÚLI MAGYAR INTÉZMÉNYEK AZ EISZ-BEN}

Az EISZ 2020-ban 250-nél is több intézmény számára biztosítja szolgáltatásait - köztük szerepel kutatóintézet, felsőoktatási intézmény, egészségügyi intézmény, szakkönyvtár,

\footnotetext{
1 LENCSÉS Ákos - SÜTŐ Péter: Online tartalmak konzorciumi beszerzése = Könyv, Könyvtár, Könyvtáros, 27. évf. 11. sz. 2018. 28-33. p.

2 EISZ - Mérföldkövek az EISZ Nemzeti Program közelmúltjából. Forrás: http://eisz.mtak.hu/index.php/hu/388-merfoldkovek-az-eisznemzeti-program-kozelmultjabol.html [2020. július 17.] 
közkönyvtár, múzeum, levéltár és államigazgatási intézmény is. Az EISZ Nemzeti Program ahogyan nevéből is következik - nem kizárólag magyarországi intézmények számára kínál szolgáltatásokat. 2015-ig azonban csak három határon túli intézmény vett részt a programban: az Erdélyi Múzeum-Egyesület, a II. Rákóczi Ferenc Kárpátaljai Magyar Főiskola és a Sapientia Erdélyi Magyar Tudományegyetem. 2018-ig további három intézmény csatlakozott az EISZ-hez: a vajdasági Európa Kollégium Egyetemista Központ, a felvidéki Fórum Kisebbségkutató Intézet és a Kolozsvári Protestáns Teológiai Intézet.

A demográfusok számításai szerint a Kárpát-medence határon túli magyarsága közel 2 millió főre tehető. Az adatok meghatározásában a népszámlálások jelentik a legnagyobb segítséget - bár szakértők felhívják a figyelmet arra, hogy a népszámlálás során felvett adatok egyes esetekben pontatlanok lehetnek, kiigazításra szorulnak. ${ }^{3}$ Különösen nehézkessé teheti az adatok értelmezését az, hogy a nemzetközi ajánlásokkal összhangban a környező országok mindegyikében önbevallásos adat a nemzetiség, ${ }^{4}$ így több esetben a nemválaszok megfelelő arányát becslésekkel számolják hozzá a ténylegesen felvett adatokhoz. ${ }^{5}$

Kapitány Balázs leírása alapján a határon túli magyar lakosság legnagyobb része $(1,2$ millió fő) a mai Románia területén él. További nagy földrajzi egységek a Felvidék (458 ezer fő), a Vajdaság (251 ezer fő) és Kárpátalja (141 ezer fő). A fentiek mellett lényegesen kisebb számban élnek magyarok Ausztria, Horvátország és Szlovénia területén. Kapitány felhívja a figyelmet arra, hogy a határon túli magyarság számának csökkenése az elmúlt években kisebb mértékúvé vált más nemzetiségekhez képest. ${ }^{6}$

Több szempontra vezethető vissza az, hogy 2018-ig a határon túli magyar intézmények viszonylagosan alacsony számban képviseltették magukat a nemzeti programban. A kutatási kibocsátás szempontjából intenzívebb, a nemzetközi tudományos világban is aktív (elsősorban felsőoktatási) intézmények nemzetközi adatbázisok iránti igényét sok esetben az adott ország konzorciumi keretein belül érvényesítették. Sok határon túli magyar intézmény azonban elsősorban magyar nyelvű online forrásokra tart igényt. Ezeknek az általában kisebb intézményeknek (elsősorban múzeumoknak, közkönyvtáraknak) az esetében az anyagi források meglehetősen korlátozottak, illetve 2018-ig az EISZ keretein belül is csak kisebb számban lehetett hozzáférni magyar nyelvű adatbázisokhoz.

\section{AZ EISZ HATÁRON TÚLI MAGYAROKAT TÁMOGATÓ PROJEKTJE}

Az EISZ Nemzeti Program fontos célkitűzése, hogy a határon túli kétmilliós magyarság számára is könnyen elérhetővé tegye szolgáltatásait. Ennek a célkitúzésnek a meg-

\footnotetext{
3 HABLICSEK László: A Kárpát-medencei magyarság előreszámítása 2021-ig = Demográfia, 48. évf. 1. sz. 2005. 83-109. p.

4 LENCSÉS Ákos: A nemzetiségi statisztika forrásai = Könyvtári Levelező/lap, 22. évf. 12. sz. 2010. 13-15. p.

5 KAPITÁNY Balázs: Kárpát-medencei népszámlálási körkép = Demográfia, 56. évf. 1. sz. 2013. 25-64. p.

6 KAPITÁNY Balázs: Kárpát-medencei népszámlálási körkép = Demográfia, 56. évf. 1. sz. 2013. 25-64. p.
} 
valósulását 2019-ben segítette elő az Innovációs és Technológiai Minisztérium (ITM) háttérintézményeként múködő Nemzeti Kutatási, Fejlesztési és Innovációs Hivatal (NKFIH) céltámogatása. A támogatásnak köszönhetően a határon túli magyar intézmények előfizetési díját (önrészét) 100\%-ban az EISZ vállalja magára, így az intézmények minden további költség nélkül férhetnek hozzá a szolgáltatásokhoz. A támogatás terhére biztosítja az EISZ az intézményi rendszerhasználati díjat, illetve a korábbi határon túli EISZ tagintézmények esetén a nemzetközi adatbázisok önrészét is.

A támogatással egy időben - bár attól függetlenül - jelentősen megnőtt a magyar nyelvű adatbázisok száma az EISZ kínálatában. 2016-ban az Akadémiai Kiadó mellett az Arcanum Digitális Tudománytár (ADT) kapott helyet a nemzeti programban a magyar adatbázis-szolgáltatók közül - az ADT egészen 2019 végéig szerepelt az EISZ kínálatában. ${ }^{7}$ 2018-ban a magyar szolgáltatói kör kiegészült a L'Harmattan Digitális Adatbázissal, a Typotex Interkönyvvel és a Tinta Kiadó által fejlesztett SzóTudásTárral, 2019-ben a Kronosz Kiadó, az Osiris Kiadó és a Szaktudás Kiadó, 2020-ban az Attraktor Kiadó, a Balassi Kiadó, a Gondolat Kiadó, a Kortárs Kiadó, a Kossuth Kiadó és a Napvilág Kiadó online adatbázisa csatlakozott az EISZ kínálatához. A Mentor Kiadó 2019-ben az ADT részeként, 2020-ben önálló adatbázisként szerepelt az EISZ portfóliójában. Érezhető, hogy a magyar szakkönyvkiadók hosszas hezitálás után, de egyre gyorsuló ütemben döntenek úgy, hogy a nyomtatott kiadványaik mellett a digitális világban is megjelenjenek. A kiadók tapasztalatai és viselkedése egymást erősítve segíti és bátorítja őket a számukra szokatlan, sok újdonságot jelentő úton. A következő években várhatóan további magyar kiadók szakkönyvei válnak adatbázisba rendezve elérhetővé a felhasználók számára.

Az NKFIH támogatása lehetővé tette valamennyi magyar adatbázis szolgáltatását a határon túli intézmények számára. Ez 2019-ben 5000, 2020-ban több mint 8200 e-könyv elérését jelentette a határon túli oktatók, kutatók, egyetemisták számára.

1. táblázat. A magyar nyelvű adatbázisokban teljes szöveggel elérhető e-könyvek száma ${ }^{8}$

\begin{tabular}{|l|c|}
\hline \multicolumn{1}{|c|}{ Adatbázis } & E-könyvek száma \\
\hline Osiris Kiadó & 1755 \\
\hline L'Harmattan Digitális Adatbázis & 1527 \\
\hline Balassi Kiadó & 886 \\
\hline Gondolat Kiadó & 756 \\
\hline Typotex Interkönyv & 647 \\
\hline
\end{tabular}

${ }^{7}$ EISZ - Tájékoztatás az Arcanum Digitális Tudománytár eléréséről. Forrás: http://eisz.mtak.hu/index.php/hu/383-tajekoztatas-az-arcanumdigitalis-tudomanytar-elereserol.html [2020. június 17.]

8 Forrás: Saját szerkesztés a kiadói címlisták alapján a 2020. március 10-i állapotnak megfelelően. 


\begin{tabular}{|l|c|}
\hline Mentor Kiadó & 633 \\
\hline Akadémiai Kiadó MeRSZ & 502 \\
\hline Napvilág Kiadó & 371 \\
\hline Szaktudás Kiadó & 323 \\
\hline Attraktor Kiadó & 243 \\
\hline Kossuth Kiadó & 227 \\
\hline Kortárs Kiadó & 174 \\
\hline Kronosz Kiadó & 144 \\
\hline Akadémiai Kiadó Szotar.net & 34 \\
\hline SzóTudásTár & 11 \\
\hline Mindösszesen & $\mathbf{8 2 3 3}$ \\
\hline
\end{tabular}

A minisztériumi céltámogatásnak köszönhetően 2019-ben 27, 2020 júniusában 34 határon túli magyar intézmény vett részt az EISZ Nemzeti Programban. A projekt első féléves szakaszát már korábban ismertettük ${ }^{9}$ az alábbiakban 2020 júliusáig mutatjuk be a projekt eredményeit.

\section{AZ NKFIH ÁLTAL TÁMOGATOTT PROJEKT KEDVEZMÉNYEZETT INTÉZMÉNYEI}

A programba bevont intézmények között települési könyvtárak, múzeumok, felsőoktatási intézmények és kutatóintézetek egyaránt megtalálhatók. Az intézmények kiválasztásánál fontos szempont volt, hogy valamennyi határon túli régióban elérhetők legyenek az EISZ-en keresztül biztosított magyar nyelvű e-könyves adatbázisok. ${ }^{10}$ 2019-ben már a Kárpát-medence valamennyi magyarlakta régiójában lehetőség volt igénybe venni a szolgáltatásokat.

2020-ban az intézményi kör jelentősen bővült a környező országok magyar nyelvű képzést biztosító felsőoktatási intézményeivel (Eperjesi Egyetem, Lucian Blaga Központi Egyetemi Könyvtár, Marosvásárhelyi Múvészeti Egyetem, Újvidéki Egyetem), illetve további települési könyvtárakat sikerült bevonni a programba. A 2020-ban biztosított minisz-

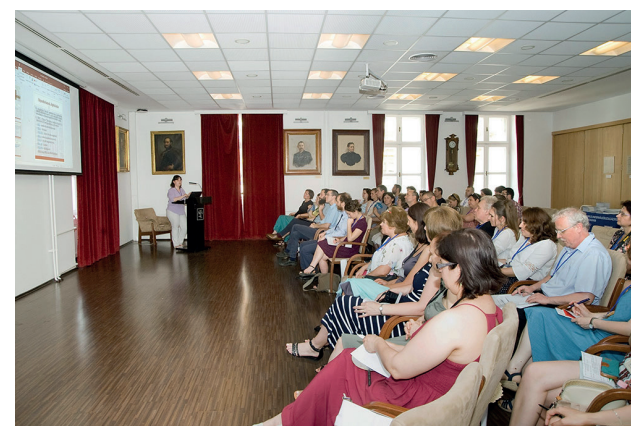

${ }^{9}$ LENCSÉS Ákos: Határon túli magyar könyvtárak az EISZ-ben. In: Kiszl Péter - Németh Katalin (szerk.) Információközvetítés és közösségépítés multifunkciós könyvtári hálózatok. Budapest, ELTE BTK Könyvtár- és Információtudományi Intézet, 2020. 163-172. p. DOI: 10.21862/infkoz.163 ${ }^{10}$ LENCSÉS Ákos: Határon túli magyar könyvtárak az EISZ-ben. In: Kiszl Péter - Németh Katalin (szerk.) Információközvetítés és közösségépítés multifunkciós könyvtári hálózatok. Budapest, ELTE BTK Könyvtár- és Információtudományi Intézet, 2020. 163-172. p. DOI: 10.21862/infkoz.163 
tériumi céltámogatás 40 intézmény részvételét teszi lehetővé, azonban az új típusú koronavírus okozta veszélyhelyzet miatt 2020 júniusában egyelőre 34 határon túli intézmény vesz részt az EISZ-ben. A kapcsolatfelvétel a további intézményekkel - elsősorban egyetemekkel és települési könyvtárakkal - 2020 elején megtörtént, és ez a kör a közintézmények újranyitásával várhatóan az év második felében már csatlakozhat a kedvezményezett intézményekhez.

1. ábra. Hozzáférési pontok 2020 júniusában ${ }^{11}$

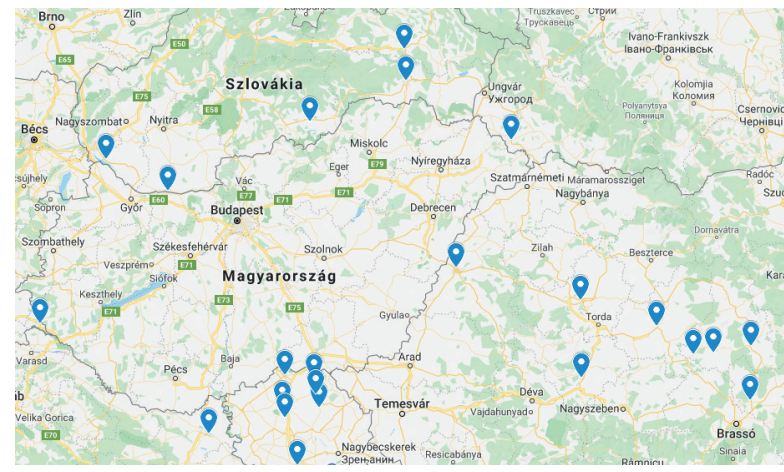

2. táblázat. Határon túli intézmények az EISZ Nemzeti Programban ${ }^{12}$

\begin{tabular}{|l|l|l|}
\hline \multicolumn{1}{|c|}{ Tájegység } & \multicolumn{1}{|c|}{ Intézmény neve } & \multicolumn{1}{c|}{ Központi telephely } \\
\hline \multirow{5}{*}{ Dél-Baranya } & Horvátországi Magyar Oktatási és Múvelődési Központ & Eszék \\
\hline \multirow{5}{*}{ Erdély, Partium } & Báró Wesselényi Miklós Városi Könyvtár & Kézdivásárhely \\
\cline { 2 - 4 } & Bod Péter Megyei Könyvtár & Sepsiszentgyörgy \\
\cline { 2 - 4 } & Csíki Székely Múzeum & Csíkszereda \\
\cline { 2 - 4 } & Erdélyi Múzeum-Egyesület & Kolozsvár \\
\cline { 2 - 4 } & Gyulafehérvári Római Katolikus Papnevelő Intézet & Gyulafehérvár \\
\cline { 2 - 4 } & Haáz Rezső Múzeum & Székelyudvarhely \\
\cline { 2 - 4 } & Jakabffy Elemér Alapítvány & Kolozsvár \\
\cline { 2 - 4 } & Kájoni János Megyei Könyvtár & Csíkszereda \\
\hline
\end{tabular}

11 Forrás: Saját összeállítás az EISZ nyilvántartása alapján a 2020. június 16-i állapotnak megfelelően.

12 Forrás: Saját szerkesztés az EISZ nyilvántartása alapján a 2020. június 16-i állapotnak megfelelően. 


\begin{tabular}{|c|c|c|}
\hline \multirow{8}{*}{ Erdély, Partium } & Kolozsvári Protestáns Teológiai Intézet & Kolozsvár \\
\hline & Lucian Blaga Központi Egyetemi Könyvtár & Kolozsvár \\
\hline & Marosvásárhelyi Múvészeti Egyetem & Marosvásárhely \\
\hline & Partiumi Keresztény Egyetem & Nagyvárad \\
\hline & Sapientia Erdélyi Magyar Tudományegyetem & Kolozsvár \\
\hline & Székely Nemzeti Múzeum & Sepsiszentgyörgy \\
\hline & Székelykeresztúri Városi Könyvtár & Székelykeresztúr \\
\hline & Székelyudvarhelyi Városi Könyvtár & Székelyudvarhely \\
\hline \multirow{5}{*}{ Felvidék } & Bocatius János Könyvtár & Kassa \\
\hline & Eperjesi Egyetem & Eperjes \\
\hline & Fórum Kisebbségkutató Intézet & Somorja \\
\hline & Matej Hrebenda Könyvtár & Rimaszombat \\
\hline & Selye János Egyetem & Révkomárom \\
\hline Kárpátalja & II. Rákóczi Ferenc Kárpátaljai Magyar Fóiskola & Beregszász \\
\hline Muravidék & Lendvai Könyvtár és Kulturális Központ & Lendva \\
\hline \multirow{10}{*}{ Vajdaság } & Európa Kollégium Egyetemista Központ & Újvidék \\
\hline & József Attila Könyvtár, Magyarkanizsa & Magyarkanizsa \\
\hline & Juhász Erzsébet Könyvtár & Topolya \\
\hline & Kishegyesi Könyvtár & Kishegyes \\
\hline & Szabadkai Városi Könyvtár & Szabadka \\
\hline & Szabadkai Városi Múzeum & Szabadka \\
\hline & Szarvas Gábor Könyvtár & Ada \\
\hline & Thurzó Lajos Művelődési-Oktatási Központ & Zenta \\
\hline & Újvidéki Egyetem & Újvidék \\
\hline & Vajdasági Magyar Művelődési Intézet & Zenta \\
\hline
\end{tabular}




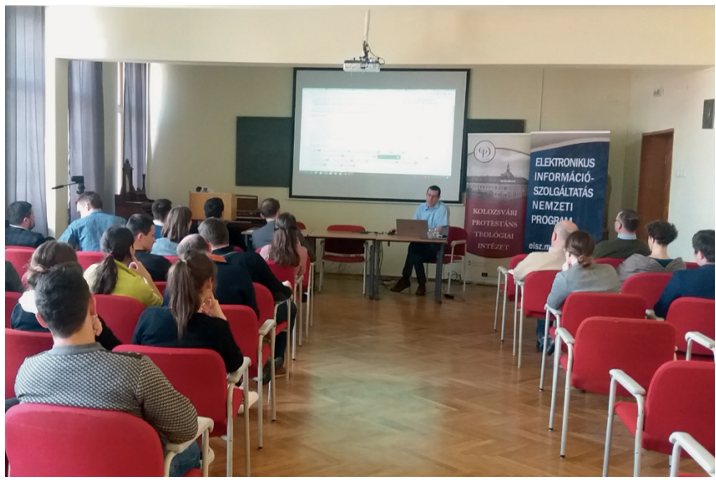

A projekt célja nem pusztán az adatbázis-hozzáférés biztosítása, hanem a határon túli magyar könyvtárosok kapcsolati hálójának erősítése is. Ebből a célból az EISZ Titkárság 2019. június 12. és 14. között háromnapos találkozót szervezett Budapesten a kedvezményezett intézmények munkatársai számára; a programon több mint hatvan fő vett részt. A személyes kapcsolatok kiépítése mellett a résztvevők megismerkedhettek az EISZ és az MTA Könyvtár és Információs Központ kutatástámogató tevékenységével: a konzorciumi szerződések munkafolyamataival, az open access szerződések előnyeivel, a COMPASS lelőhely-adatbázis működésével, a Magyar Tudományos Művek Tára (MTMT) felépítésével, az Akadémiai Könyvtár és a WorldCat kapcsolatával. Emellett lehetőség nyílt megismerkedni a kiadók és adatbázis-szolgáltatók képviselőivel, illetve részt venni közösségteremtő kulturális programokon - ez utóbbiak közé tartozik az Országház, az Ünnepi Könyvhét, illetve a Magyar Nemzeti Galéria megtekintése. A szakmai együttműködést jól jelzi, hogy a projekt következtében több esetben került sor intézmények közti tapasztalatcserére, illetve a kapcsolatoknak köszönhetően Erasmus-ösztöndíj keretében lehetőség nyílt többnapos intézménylátogatásra is.

A résztvevőktől érkezett rendkívül pozitív visszajelzések, illetve a 2020 első félévében csatlakozott intézmények képviselőivel való személyes találkozás miatt az EISZ 2020 májusára tervezte a projekt második évének találkozóját, amelyre a veszélyhelyzet kihirdetése és az utazási korlátozások miatt nem kerülhetett sor.

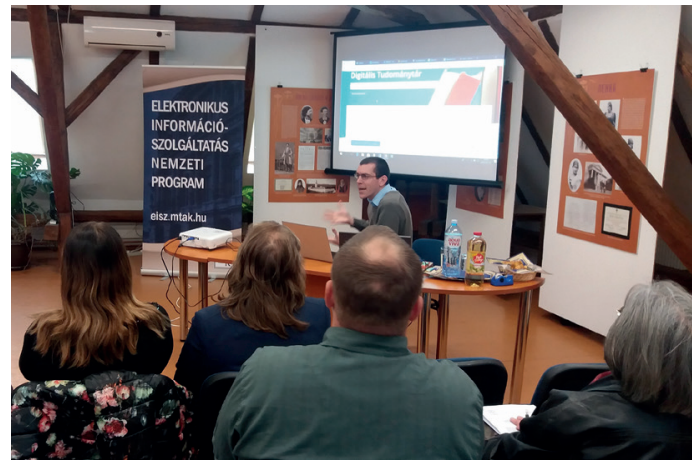

\section{AZ ADATBÁZISOK HASZNÁLATI MUTATÓI}

Az egyes adatbázisok használati adatait nehéz összehasonlítani a különböző e-könyves formátumok miatt. A MeRSZ nagyon rövid, néhány oldalas fejezetekre tagolja a szakkönyveit. A Typotex Interkönyv esetén lehetőség van teljes könyv vagy az egyes könyvfejezetek egymást követő megnyitására. A Szaktárs felületen elérhető e-könyveknél egyszerre megnyílik a teljes könyv, és a felhasználó 50 oldalig tetszőleges terjedelemben menthet 
el könyvrészleteket. Így előfordulhat, hogy egy hasonló méretű könyvrészlet megnyitása, elmentése a különböző adatbázisokban 1, 5 vagy akár 25 megtekintést eredményez a használati statisztikában - sőt akár egy adatbázison belül is lehetnek eltérések a használattól függően az alapján, hogy a felhasználó egyben nyitja meg az e-könyvet vagy fejezetenként, oldalanként.

Az e-könyv-formátumok és az eltérő funkcionalitással rendelkező adatbázisok összehasonlítási nehézségére a nemzetközi szakirodalom is elhívja a figyelmet. ${ }^{13}$ Éppen ezért a projekt keretében elérhető szolgáltatások használati adatait körültekintően kell értelmezni, és figyelni kell arra, hogy a puszta számadatok milyen tényleges használatra mutatnak rá. ${ }^{14} \mathrm{~A}$ fenti nehézségek mellett is megfigyelhető néhány egyértelmű trend a projekt használati adatai alapján.

3. táblázat. A 15 legnagyobb használatot mutató intézmény használati adatai 2019-ben ${ }^{15}$

\begin{tabular}{|l|l|}
\hline \multicolumn{1}{|c|}{ Intézmény } & Adatbázis-használati adatok 2019-ben ${ }^{16}$ \\
\hline Sapientia Erdélyi Magyar Tudományegyetem & 7740 \\
\hline Kolozsvári Protestáns Teológiai Intézet & 6882 \\
\hline Erdélyi Múzeum-Egyesület & 5723 \\
\hline Selye János Egyetem & 4947 \\
\hline II. Rákóczi Ferenc Kárpátaljai Magyar Főiskola & 3074 \\
\hline Juhász Erzsébet Könyvtár & 2826 \\
\hline Partiumi Keresztény Egyetem & 2668 \\
\hline Bocatius János Könyvtár & 1763 \\
\hline Fórum Kisebbségkutató Intézet & 1502 \\
\hline Haáz Rezső Múzeum & 1376 \\
\hline Marosvásárhelyi Múvészeti Egyetem & 1041 \\
\hline Szabadkai Városi Könyvtár & 1023 \\
\hline
\end{tabular}

\footnotetext{
13 CONYERS, Angela [et al.]: E-book Usage: Counting the Challenges and Opportunities. = Insights, 30. évf. 2. sz. 2017. 23-30. p. DOI: 10.1629/uksg.370. Magyar nyelvŭ ismertetését Id.: LENCSÉS Ákos: Az e-könyv-használati statisztika kérdései. = Tudományos és Műszaki Tájékoztatás, 64. évf. 9. sz. 2017. 446-447. p.

${ }^{14} \mathrm{Az}$ adatok összegyűjtésében és azok értelmezésében Sütő Péter, az EISZ könyvtárosa nyújtott segítséget.

15 Forrás: Saját szerkesztés az EISZ nyilvántartása alapján. EISZ - Statisztika. Forrás: http://eisz.mtak.hu/index.php/hu/statisztika.html [2020. június 17.]

${ }^{16}$ Valamennyi magyar nyelvű adatbázis használatát számolva, összeadva a dokumentum-megtekintések és szócikk-megjelenítések számát.
} 


\begin{tabular}{|l|c|}
\hline Kishegyesi Könyvtár & 783 \\
\hline Lendvai Könyvtár és Kulturális Központ & 771 \\
\hline Európa Kollégium Egyetemista Központ & 755 \\
\hline
\end{tabular}

2019-ben a 27 kedvezményezett intézmény statisztikája alapján jelentősebb a használat azokban az intézményekben, amelyek korábban is részt vettek az EISZ-ben, és így a meg előző években már lehetőségük nyílt az adatbázisokat megismertetni a felhasználói körrel, integrálni a szolgáltatásokat az intézményi munkafolyamatokba (kiemelkedő a használat a Sapientia Erdélyi Magyar Tudományegyetem, a Kolozsvári Protestáns Teológiai Intézet, az Erdélyi Múzeum-Egyesület és a II. Rákóczi Ferenc Kárpátaljai Magyar Főiskola esetén). Az sem meglepő, hogy az adatbázisok használata jelentősebb a felsőoktatási intézményeknél, a Sapientia Erdélyi Magyar Tudományegyetem és a Kolozsvári Protestáns Teológiai Intézet mellett a Selye János Egyetem és a Partiumi Keresztény Egyetem használati adatai is kiemelten magasak. Ugyanakkor más intézménytípus esetén is jelentős használat figyelhető meg: így a Juhász Erzsébet Könyvtár és a Bocatius János Könyvtár is aktív használója az adatbázisoknak, ami azt mutatja, hogy a közkönyvtári felhasználók részéről is igény van a szolgáltatásokra - a könyvtáraknak azonban tudatosan népszerüsíteni kell ezeket a lehetőségeket az olvasóik körében.

Az adatok alapján érezhető, hogy az intézmények jelentős részénél még a bevezetés szakaszában jár az adatbázisok megismertetése a felhasználói körrel. Ezek a szolgáltatások újdonságot jelentettek az intézményi munkatársaknak és az olvasók számára is. Ezt felismerve az EISZ munkatársai több esetben helyszíni képzésen mutatták be az adatbázisokat: 2019-ben nyolc helyszínen, összesen több mint háromszáz fő részvételével zajlottak ezek az események. 2020-ban is egyeztetés alatt álltak az adatbázis-használatot népszerűsítő kampány állomásai, azonban az új típusú koronavírus miatt kihirdetett veszélyhelyzet nem tette lehetővé ezek megtartását.

4. táblázat. A 10 legnagyobb használatot mutató intézmény használati adatai 2020 első félévében

\begin{tabular}{|l|c|}
\hline \multicolumn{1}{|c|}{ Intézmény } & Adatbázis-használati adatok 2020 első félévében ${ }^{17}$ \\
\hline Partiumi Keresztény Egyetem & 4051 \\
\hline Lucian Blaga Központi Egyetemi Könyvtár & 3520 \\
\hline Sapientia Erdélyi Magyar Tudományegyetem & 3098 \\
\hline Juhász Erzsébet Könyvtár & 1674 \\
\hline
\end{tabular}

17 Valamennyi magyar nyelvű adatbázis használatát számolva, összeadva a dokumentummegtekintések és szócikk-megjelenítések számát. 


\begin{tabular}{|l|c|}
\hline Kolozsvári Protestáns Teológiai Intézet & 1607 \\
\hline Selye János Egyetem & 1048 \\
\hline Európa Kollégium Egyetemista Központ & 843 \\
\hline Erdélyi Múzeum-Egyesület & 727 \\
\hline Fórum Kisebbségkutató Intézet & 534 \\
\hline Bod Péter Megyei Könyvtár & 491 \\
\hline
\end{tabular}

A 2020 első félévi használati adatok megbízhatóságát a fejezet elején ismertetett statisztikai szempontok mellett további tényezők is befolyásolják. Az új típusú koronavírus okozta járványhelyzet miatt az intézmények jelentős része bezárt. Az egyetemek, kutatóintézetek, közkönyvtárak munkatársai otthoni munkavégzés keretében igyekeztek kiszolgálni a távhasználatra kényszerült felhasználókat. A helyzetet felismerve - és a nemzetközi kiadói trendekhez igazodva - a magyar adatbázis-szolgáltatók is igyekeztek támogatni a távhasználatot. A Typotex Interköny és a Kossuth Kiadó intézményi jelszóval segítette a távhasználatot. Az Akadémiai Kiadó és a Szaktárs felületen elérhető szakkiadók felhasználói azonosítás nélkül megnyitották az adatbázisok elérését, a SzóTudásTár intézményhez nem köthető központi jelszóval segítette az adatbázis elérését. A távhasználat elősegítése összességében a használat jelentős növekedését jelentette. Azonban a számtalan pozitív következmény mellett az eljárás egyes esetekben az intézményi statisztikák torzítását okozta. Korábban az egyetemi oktatók és hallgatók az intézmény IP-címéről érték el az e-könyveket, de a nyílt hónapok alatt minden felhasználó (eduID azonosítás vagy VPN nélkül) az otthoni számítógépéről is hozzáfért kiadványokhoz. Így a használatot már nem lehet egy-egy intézményhez kötni. Bár egyértelműnek tekinthető, hogy a könyvtárak, egyetemek, közintézmények bezárása elősegítette az online tartalmak használatának növekedését - és ez tükröződik az intézményi adatokban is -, pontos képünk sajnos nincs az intézményi használatról. Az egy-egy intézményhez köthető használat a bemutatott statisztikánál vélhetően jobban növekedett.

A féléves adatok alapján még így is egyértelmű, hogy az intézmények teljes 2020. évi használata jelentősen meghaladja majd a megelőző évet. Ez különösen szép eredmény annak fényében, hogy a fent bemutatott szempontok lefelé torzítják a használati adatokat, illetve kikerült a portfólióból a 2019-ben jelentős használatot elérő Arcanum Digitális Tudománytár. A használat ilyen jelentős növekedése vélhetően több szempontnak köszönhető. Egyrészt természetesen a hozzáférhető adatbázisok és az e-könyvek körének bővülése segítette a használat növekedését. Másrészt a könyvtárosoknak, oktatóknak köszönhetően az intézmények felhasználói körében, a felsőoktatási intézmények gyakorlatában is sikerült jobban meghonosítani az online tartalmakat. 


\section{ÖSSZEFOGLALÁS}

A projekt koncepciója, hogy a határon túli magyar intézmények és így a határon túli magyar közösségek számára online szakirodalmi és közművelődési forrásokat biztosítson. A céltámogatás terhére a határon túli intézmények adatbázis-előfizetését 100\%-ban támogatja az EISZ, de emellett több más cél is teljesülhet a nemzeti programban. Így például lehetőség nyílt a nemzeti programban már korábban részt vevő intézmények adatbázis-hozzáférésének bővítésére; az adatbázis-használat elősegítése céljából egyéni konzultációk és tréningek szervezésére; illetve sikerült több határon túli intézményt bevonni az EISZ-be.

A projekt alapvető feladata az online szolgáltatások biztosítása a kedvezményezett intézmények és felhasználóik számára. Ez a célkitűzés azonban szerencsésen találkozott a felhasználói igényekkel, valamint a határon túli magyar könyvtárosok is rendkívül aktívan igyekeztek és igyekeznek az új lehetőségeket megismertetni a felhasználói körükkel. Így a tartalomszolgáltatás mellett új kapcsolatokat születhettek, illetve az intézményi képviselők szakmai fórumokon oszthatták meg egymással tapasztalataikat. Az adatbázis-használati adatok egyértelműen mutatják, hogy a határon túli magyarság részéről jelentős igény van a magyar nyelvű e-könyves adatbázisokra. A határon túli intézményi hálózat közkönyvtárai, felsőoktatási könyvtárai és további szakkönyvtárai minden lehetséges módon igyekeznek megfelelni ezen igénynek.

A céltámogatásnak köszönhetően 2019-ben 27 határon túli intézmény férhetett hozzá 5000 magyar e-könyvhöz, 2020 első félévében pedig már 34 intézmény számára 8200 kötet elérését lehetett biztosítani. A támogatás felhasználása így egyszerre segíti a határon túli magyarság szakirodalmi és közművelődési ellátását, a kedvezményezett könyvtárak szolgáltatásainak bővítését, illetve az EISZ-nek mint nemzeti programnak a teljes magyarságot kiszolgáló stratégiai céljait.

IRODALOMJEGYZÉK

CONYERS, Angela [et al.]: E-book Usage: Counting the Challenges and Opportunities. = Insights, 30. évf. 2. sz. 2017. 23-30. p. DOI: 10.1629/uksg.370

EISZ - Mérföldkövek az EISZ Nemzeti Program közelmúltjából. Forrás: http://eisz.mtak.hu/index.php/ hu/388-merfoldkovek-az-eisz-nemzeti-program-kozelmultjabol.html [2020. július 17.]

EISZ - Statisztika. Forrás: http://eisz.mtak.hu/index.php/hu/statisztika.html [2020. június 17.]

EISZ - Tájékoztatás az Arcanum Digitális Tudománytár eléréséról. Forrás: http://eisz.mtak.hu/index.php/ hu/383-tajekoztatas-az-arcanum-digitalis-tudomanytar-elereserol.html [2020. június 17.] 
HABLICSEK László: A Kárpát-medencei magyarság előreszámítása 2021-ig = Demográfia, 48. évf. 1. sz. 2005. 83-109. p.

KAPITÁNY Balázs: Kárpát-medencei népszámlálási körkép = Demográfia, 56. évf. 1. sz. 2013. 25-64. p.

LENCSÉS Ákos: Határon túli magyar könyvtárak az EISZ-ben. In: Kiszl Péter - Németh Katalin (szerk.) Információközvetítés és közösségépítés - multifunkciós könyvtári hálózatok. Budapest, ELTE BTK Könyvtár- és Információtudományi Intézet, 2020. 163-172. p. DOI: 10.21862/infkoz.163

LENCSÉS Ákos - SÜTŐ Péter: Online tartalmak konzorciumi beszerzése = Könyv, Könyvtár, Könyvtáros, 27. évf. 11. sz. 2018. 28-33. p.

LENCSÉS Ákos: A nemzetiségi statisztika forrásai = Könyvtári Levelező/lap, 22. évf. 12. sz. 2010. 13-15. p.

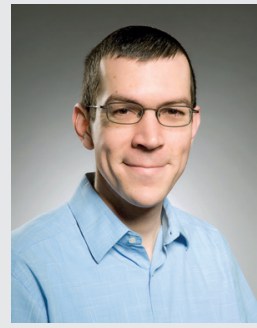

Dr. Lencsés Ákos (ORCID: 0000-0003-4461-1105)

Könyvtáros diplomáját 2004-ben, matematika tanári diplomáját 2006-ban szerezte az Eötvös Loránd Tudományegyetemen; könyvtártudományi doktori értekezését 2020-ban védte meg az intézményben. 2012-ben az Az év fiatal könyvtárosa-díj kitüntetettje, 2013 óta a Kodolányi János Egyetem óraadó oktatója. 2002 és 2006 között a jelenlegi Budapesti Corvinus Egyetem központi könyvtárában, 2007 és 2015 között a Központi Statisztikai Hivatal könyvtárában dolgozott. 2015 óta az EISZ Nemzeti Program fökönyvtárosa, illetve az Intézményi Koordinációs Osztály vezetője. 